\title{
EVALUATION OF ANTIOXIDANT AND ANTI-INFLAMMATORY PROPERTIES OF AQUEOUS EXTRACT OF WILD MUSHROOMS COLLECTED FROM HIMACHAL PRADESH
}

\author{
AARTI BAINS*, ASTHA TRIPATHI \\ Department of Biotechnology, Shoolini University, Solan, Himachal Pradesh, India. \\ Email: aarti05888@gmail.com
}

Received: 10 December 2016, Revised and Accepted: 28 December 2016

\section{ABSTRACT}

Objective: The objective of this study is to elucidate phytochemical contents, antioxidant, and anti-inflammatory activity of wild mushrooms collected from Himachal Pradesh.

Methods: Quantitative analysis of phytochemical constituents was carried out using standard methods while 1,1 diphenylpicrylhydrazyl nitric oxide, hydrogen peroxide-free radical scavenging assay were used to evaluate the antioxidant properties of selected wild mushrooms. Anti-inflammatory capacity of samples was evaluated by human red blood cell membrane stabilization and albumin denaturation inhibition method.

Results: The results obtained revealed that Pleurotus floridanus showed higher total phenol, flavonoid carotenoid, and ascorbic acid contents of $61.13 \pm 2.3 \mathrm{mg} / \mathrm{g}, 15.2 \pm 1.13 \mathrm{mg} / \mathrm{g}, 12.42 \pm 0.42 \mu \mathrm{g} / \mathrm{g}, 17.36 \pm 0.40 \mu \mathrm{g} / \mathrm{g}$, and $14.55 \pm 0.58 \mathrm{mg} / \mathrm{g}$. All the species showed antioxidant potential, but P. floridanus proved to be more active while Macrocybe sp. proved to be least one.

Conclusion: The mushroom species analyzed have been showed to be good source of phytoconstituents, antioxidants, and also possess antiinflammatory properties, thus can be used in the management of oxidative stress-induced disease.

Keywords: Wild mushrooms, Scavenging effect, Total phenol, Antioxidant, Anti-inflammatory.

(C) 2017 The Authors. Published by Innovare Academic Sciences Pvt Ltd. This is an open access article under the CC BY license (http://creativecommons. org/licenses/by/4. 0/) DOI: http://dx.doi.org/10.22159/ajpcr.2017.v10i3.16547

\section{INTRODUCTION}

Wild mushrooms since primords of human civilization have been extensively consumed mainly due to their delicate and unique flavor and taste they provide, having high amounts of water, protein fiber, and carbohydrates, and being rich in sources and minerals [1-4]. In mushrooms, lipids are present in low values which make them as valuable foods due to low-calorie and fat content food [2-4]. Due to these properties, their marketability, and economic contribution enhances by approximately two billion dollars [5]. Beyond these nutritional characteristics, mushrooms due to their richness in bioactive compounds that presented anticancer, antioxidant, and antimicrobial properties extensively studied for their medicinal properties $[4,6,7]$. The growing emergence of drug resistance bacterial strains is a serious threat to humankind for the effective treatment of infections; hence, to minimize the development of drug resistance strains it is important to choose the most appropriate antibiotics and to use them appropriately [8]. Stress on the body due to aging, obesity, and detrimental lifestyles are another significant health issue which often takes the form of oxidative tissue damage. In human body, during energy production in the mitochondrial respiratory chain, phagocytosis, fertilization, arachidonic acid metabolism, and xenobiotic metabolism-free radicals are constantly formed. Free radicals such as hydroxyl radicals $(-\mathrm{OH})$, superoxide radicals and hydrogen peroxide radicals $\left(\mathrm{H}_{2} \mathrm{O}_{2}\right)$ damage DNA, provoke uncontrolled chain reactions including lipid peroxidation which leads to the development of cancer, impair enzymes and structural proteins, neurological and cardiovascular diseases, cataracts, rheumatoid arthritis, and diabetes $[9,10]$. Reactive oxygen species activate nuclear factors; thus, inducing the synthesis of cytokines and therefore are responsible in the development of systemic inflammatory response syndrome. Adhesion molecules and inflammatory mediators are also formed later. Free radicals lead to loss of function and cell death by reacting with different cell components at site of inflammation [11]. All organisms have defense systems which are not sufficient to protect against free radicals. Synthetic antioxidants including hydroxyanisole and butylated hydroxytoluene have side effects and thought to be responsible for liver damage and carcinogenesis [12]. As a result, natural antioxidants such as vitamin $\mathrm{A}, \mathrm{C}$, and $\mathrm{E}$, carotenoids, flavonoids, and other simple phenolic compounds are preferred in food applications to prevent oxidative damage and to protect the human body [13]. Although many studies on nutrient compositions of different mushroom species have been done. The present study sought to investigate the antioxidant and anti-inflammatory activity of aqueous extract of mushrooms collected from Himachal Pradesh. The antioxidant activity of the mushrooms extract was assessed by measuring their free radical scavenging activity.

\section{METHODS}

\section{Sample collection}

Fruiting bodies of three mushrooms were collected from the forests of Solan and Baru Sahib and were labeled as sample no. 104, 105, and 127. The fruiting bodies were brought to laboratory in sterile plastic bags washed thoroughly with sterile distilled water and $0.001 \%$ mercuric chloride and with the aid of sterile blade; these were aseptically break lengthwise exposing the inner tissue. A small piece of tissue from each sample was aseptically transferred on to the plates of malt extract agar. Three wild isolates, namely, Calocybe indica, Agrocybe aegerita, and Macrocybe sp. were procured from Directorate of Mushroom Research Centre, Solan India.

\section{Identification of fruiting bodies}

The fruiting bodies of three unknown collected mushrooms were identified as Pleurotus floridanus (KU 925874), P. ostreatus (KU 892064), and Trametes versicolor (KU 892065) on the basis their morphological feature and molecular characterization. 
Determination of bioactive compounds

Standards L- ascorbic acid, quercetin, gallic acid, Ferrous sulfate, Sodium salicylate, Folin - Ciocalteu reagent, 1,1-Diphenyl-2 picrylhydrazyl (DPPH), and naphthylethylene diaminedihydrochloride was obtained from Sigma (St. Louis, MO, USA). All other chemicals and solvents were of analytic grade.

\section{Phenolic compound estimation}

Extraction solution $(100 \mu \mathrm{l})$ was mixed with $1.5 \mathrm{ml}$ of folin-ciocalteu reagent and allowed to incubate at room temperature for one minute followed by the addition of sodium carbonate $(60 \mathrm{~g} / \mathrm{l})$. The tubes were then vortex-mixed for about 15 seconds, and then, allowed to stand for 90 minutes in the dark at room temperature. Absorbance was then measured at $725 \mathrm{~nm}$. Gallic acid was used as standard curve with concentration ranges from 1 to $100 \mu \mathrm{g} / \mathrm{ml}\left(\mathrm{R}^{2}=0.996\right)$, and the results were expressed as mg gallic acid equivalent (GAE)/g DW. All experiments were performed in triplicates [14].

\section{Flavonoid contents}

A volume of $1.25 \mathrm{ml}$ of distilled water was mixed with $250 \mu \mathrm{l}$ extracts of mushrooms and $75 \mu \mathrm{l}$ of $5 \% \mathrm{NaNO}_{2}$ solution. After 5 minutes, $150 \mu \mathrm{l}$ of $10 \% \mathrm{AlCl}_{3}$. $\mathrm{H}_{2} \mathrm{O}$ was added, and then, $275 \mu \mathrm{l}$ of distilled water and $500 \mu \mathrm{l}$ of $1 \mathrm{M} \mathrm{NaOH}$ were added to the mixture after 6 minutes. The solution was then mixed well and intensity of pink color was measured at $510 \mathrm{~nm}$. Quercetin with concentration range of $20-100 \mu \mathrm{g} / \mathrm{ml}$ $\left(R^{2}=0.9938\right)$ was used for calibration curve. The results were expressed as milligram of $(+)$ quercetin equivalent (CEs) per gram of extract [15].

\section{Ascorbic acid determination}

The dried mycelial extract (100 mg) was extracted with $10 \mathrm{ml}$ of $1 \%$ metaphosphoric acid for 45 minutes at room temperature and filtered through Whatman no.4 filter paper. $1 \mathrm{ml}$ of filtrate was then mixed with $9 \mathrm{ml}$ of 2, 6 dichloroindophenol, and absorbance was measure within 30 minutes at $515 \mathrm{~nm}$ against a blank. The content of ascorbic acid would be calculated on the basis of calibration cure of authentic $\mathrm{L}$-ascorbic with concentration range of $2-125 \mu \mathrm{g} / \mathrm{ml}\left(\mathrm{R}^{2} 0.9929\right)$. All experiments were performed in triplicates [16].

\section{$\beta$-carotene and lycopene determination}

$100 \mathrm{mg}$ of dried extract was vigorously shaked with $10 \mathrm{ml}$ of acetonehexane mixture $(4: 6)$ for one minute and filtered through Whatman no. 4 filter paper. The absorbance of filtrate was then measured at 453 , 505 , and $663 \mathrm{~nm}[17]$

Content of $\beta$-carotene and lycopene were calculated using following equations

Lycopene $(\mathrm{mg} / 100 \mathrm{ml})=-0.0458 \mathrm{~A} 663+0.372 \mathrm{~A} 505-0.0806 \mathrm{~A} 453$

$\beta$-carotene $(\mathrm{mg} / 100 \mathrm{ml})=0.216 \mathrm{~A} 663-0.304 \mathrm{~A} 505+0.452 \mathrm{~A} 453$.

\section{Antioxidant activity determination \\ DPPH scavenging activity}

Free radical scavenging activity of aqueous extract of all isolates of mushrooms was determined by DPPH method. $0.1 \mathrm{mM}$ of DPPH solution was prepared in methanol, and $0.5 \mathrm{ml}$ was added to $0.5 \mathrm{ml}$ of extract. The mixture was then vortexed thoroughly and left for 45 minutes in the dark at room temperature. The absorbance was measured at $515 \mathrm{~nm}$ against blank. A lower absorbance represents higher DPPH scavenging activity. The capability of scavenging DPPH radicals was calculated using following equation

DPPH scavenging effect $(\%)=(1-\mathrm{As} / \mathrm{Ac}) \times 100$

Where AC is the absorbance of control containing DPPH solution and AS is absorbance of extract solution containing DPPH [18].

\section{Nitric oxide scavenging assay}

Nitrite detection method was used to assess the interaction of extract of macro-fungi with nitric oxide. Sodium nitroprusside $(10 \mathrm{mM})$ in $0.5 \mathrm{M}$ phosphate buffer $\mathrm{pH} 7.4$ which spontaneously produced nitric oxide in aqueous solution was used as chemical source. Nitric oxide interacts with oxygen to produce stable products which lead to the production of nitrites.

A volume of $5 \mathrm{ml}$ of riess reagent ( $\alpha$-napthylethylenediamine $0.1 \%$ in water and sulfanilic acid $1 \%$ in $\mathrm{H}_{3} \mathrm{PO}_{4}$ ) was added after incubation for $5 \mathrm{hrs}$ at $37^{\circ} \mathrm{C}$. The absorbance of the solution was measured at $546 \mathrm{~nm}$ [19].

\section{Hydrogen peroxide-free radical scavenging activity}

A solution of $\mathrm{H}_{2} \mathrm{O}_{2}(40 \mathrm{mM})$ was prepared in phosphate buffer $(7.4 \mathrm{pH})$. The concentration of $\mathrm{H}_{2} \mathrm{O}_{2}$ was determined by absorption at $230 \mathrm{~nm}$ using spectrophotometer. Extracts $(100-1000 \mu \mathrm{g} / \mathrm{ml})$ were then added to $\mathrm{H}_{2} \mathrm{O}_{2}$ solution, and after 10 minutes of incubation, the absorbance was determined at $230 \mathrm{~nm}$. Phosphate buffer without $\mathrm{H}_{2} \mathrm{O}_{2}$ was used as blank. Ascorbic acid was used as standard curve [20].

\section{Anti-inflammatory activity}

Human red blood cell (HRBC) membrane stabilization assay

Blood was collected from healthy volunteer who was not taken nonsteroidal anti-inflammatory drugs (NSAID) for two weeks. The collected blood was mixed with equal volume of sterilized alsever solution $(2 \%$ dextrose, $0.8 \%$ sodium citrate, $0.5 \%$ citric acid, and $0.42 \%$ sodium chloride in water). It was centrifuged at $3000 \mathrm{rpm}$ for 15 minutes. Packed cell was washed with isosaline. Different concentration of extract $(100,500$, and 1000 and $2000 \mu \mathrm{g} / \mathrm{ml}$ ) was prepared in isosaline. The assay mixture contained $0.5 \mathrm{ml}$ of extract $1 \mathrm{ml}$ phosphate buffer (0.15M, pH 7.4) $2 \mathrm{ml}$ of hyposaline (0.36\%), and $0.5 \mathrm{ml} \mathrm{HRBC}$ suspension and incubated at $3^{\circ} \mathrm{C}$ for 30 minutes and then centrifuged at $3000 \mathrm{rpm}$ for 20 minutes. Diclofenac sodium was used as reference standard. Instead of hyposaline $2 \mathrm{ml}$ of distilled water was used as control. The hemoglobin content in supernatant solution was estimated using spectrophotometer at $560 \mathrm{~nm}$ [21].

$\%$ hemolysis was calculated by

$\%$ inhibition of hemolysis $=100($ OD1-OD2) $/$ OD 1

$\%$ stabilization of HRBC membrane stabilization was calculated as:

$\%$ age protection $=100-(\mathrm{OD} 2 / \mathrm{OD} 1) \times 100$

Where,

OD1 = Optical density of hypotonic buffer saline alone (control).

OD2 = Optical density of test sample in hypotonic buffer saline solution.

\section{Albumin denaturation assay}

A volume of $5 \mathrm{ml}$ of reaction consist of $0.2 \mathrm{ml}$ of egg albumin (from fresh hen's egg), $2.8 \mathrm{ml}$ of phosphate buffer saline (pH 6.4), and $2 \mathrm{ml}$ of varying concentration of aqueous extracts of each samples so that final concentrations become 100, 500, 1000, and $2000 \mu \mathrm{g} / \mathrm{ml}$. The distilled water was used as control. The mixture was then incubated at $37^{\circ} \mathrm{C}$ in a BOD incubator for 15 minutes and then heated at $70^{\circ} \mathrm{C}$ for 5 minutes. After cooling, the absorbance was measured at $660 \mathrm{~nm}$. Diclofenac sodium was used as reference drug [22].

The percentage inhibition of protein denaturation was calculated using following formula.

$\%$ inhibition $=100 \times(\mathrm{Vt} / \mathrm{Vc}-1)$

$\mathrm{Vt}=$ absorbance of test sample

$\mathrm{Vc}=$ absorbance of control

Statistical analysis

All the experimental analysis was carried out in triplicates. The results are expressed as mean values and standard deviation. The results were analyzed using one-way analysis of variance, (ANOVA) followed 
by Turkey's HSD test using SAV v.9.1.3 program. Differences at $\mathrm{p}<0.05$ were considered to be statistically significant.

\section{RESULTS}

\section{Quantitative phytochemical analysis}

The determination of quantitative phytochemical content of aqueous extracts of selected mushrooms results as given in Table 1 revealed that total contents of phenols ranges from $22.46 \pm 1.87$ to $53.3 \pm 0.93 \mathrm{mg} / \mathrm{g}$, total flavonoid contents ranges from $2.97 \pm 0.11$ to $12.91 \pm 0.11 \mathrm{mg} / \mathrm{g}$, total ascorbic acid contents ranges from $2.77 \pm 0.03$ to $12.01 \pm 0.89 \mathrm{mg} / \mathrm{g}$, total $\beta$ carotene contents ranges from $0.979 \pm 0.42$ to $8.384 \pm 0.42 \mu \mathrm{g} / \mathrm{g}$, and total lycopene content ranges from $1.75 \pm 0.51$ to $6.57 \pm 0.49$. The extract of mushroom $P$. floridanus had the highest amount of phenol content $(61.13 \pm 2.3 \mathrm{mg} \mathrm{GAE} / \mathrm{g})$ while Macrocybe sp. had least amount of phenol present $(22.46 \pm 1.87 \mathrm{mg} \mathrm{GAE} / \mathrm{g})$. Flavonoids and ascorbic acid were also obtained but in small amount in comparison to phenolic compounds while $\beta$ - carotene and lycopene were found in vestigial amount $(>91 \mu \mathrm{g} / \mathrm{g})$ as shown in Table 1.

\section{Evaluation of bioactivities of aqueous extracts of isolates}

For in-vitro evaluation of antioxidant properties of mycelial aqueous extract from different isolates multiple assays based on different antioxidant mechanisms were carried out these were DPPH radicals, hydrogen peroxide, and nitric oxide-free radical scavenging activity assays.

\section{DPPH-free radical scavenging activity}

DPPH being stable-free radical has advantage of being unaffected by certain side reaction such as metal ion chelation and enzyme inhibition [23]. Freshly prepared DPPH exhibit purple deep color with absorption maximum at $517 \mathrm{~nm}$, the deep purple of DPPH disappears due to quenching of its free radicals by antioxidants present in the medium, i.e., by providing hydrogen atom or by electron donation, through free radical attack on DPPH molecule, and convert them to a colorless bleached product, 2,2 diphenyl-1 hydrazine. As shown in Table 2 at $100-1000 \mu \mathrm{g} / \mathrm{ml}$, the scavenging ability of aqueous extract was highest for P. floridanus ranges from $44.4 \pm 0.06$ to $64.16 \pm 0.21$ followed by $P$. ostreatus ranges from $41.3 \pm 0.25$ to $62.33 \pm 0.15$, T. versicolor $38.5 \pm 0.01$ to $60.56 \pm 0.12$, C. indica $28.5 \pm 0.1$ to $47.06 \pm 0.15$, Agrocybe aegerita $24.86 \pm 0.15$ to $45.36 \pm 0.06$, Macrocybe sp. $21.06 \pm 0.2$ to $38.76 \pm 0.15$, respectively. Ascorbic acid was taken as standard which showed excellent scavenging activity of $82.96 \pm 0.2 \%$ as shown in Table 2 .

\section{Nitric oxide-free radical scavenging assay}

Nitric oxide radical is associated with the development of inflammatory disorders [24]. Nitric oxide radicals generated from sodium nitroprusside were found to be inhibited by all aqueous extracts, as shown in Table 3. The aqueous extract of isolate P. floridanus showed maximum percentage inhibition effect on nitric oxide ranges which ranges from $28.23 \pm 0.05$ to $62.83 \pm 0.11$ followed by $P$. ostreatus having percentage inhibition effect ranges from $27.13 \pm 0.06$ to 60.76 , T. versicolor $24.7 \pm 0.12$ to $56.37 \pm 0.06$, C. indica $22 \pm 0.17$ to $49.03 \pm 0.2$, Agrocybe aegerita $20.06 \pm 0.2$ to $36.1 \pm 0.17$, and Macrocybe sp. having inhibition effect ranges from $18.42 \pm 0.04$ to $33.63 \pm 0.05$. Ascorbic acid was taken as standard showing excellent inhibition of nitric oxide radicals generated from sodium nitroprusside with percentage inhibition ranging from $30.45 \pm 0.08$ to $83 \pm 0.17$ as shown in Table 3 .
Hydrogen peroxide-free radical scavenging assay

Hydrogen peroxide scavenging activity of selected mushrooms is shown in Table 4. All the mushrooms scavenge $\mathrm{H}_{2} \mathrm{O}_{2}$ in a dose- dependent manner. P. floridanus has highest $\mathrm{H}_{2} \mathrm{O}_{2}$ scavenging activity with value ranging from $39.46 \pm 0.15$ to 62.21 while Macrocybe sp. has least scavenging activity with value ranging from $22.23 \pm 0.15$ to $43.83 \pm 0.11$. Ascorbic acid was taken as standard showing the excellent scavenging activity of $\mathrm{H}_{2} \mathrm{O}_{2}$ with percentage inhibition ranging from, $46.69 \pm 0.2$ to $82.99 \pm 0.11$.

\section{Anti-inflammatory activity}

The aqueous extracts were studied for their in vitro anti-inflammatory activity by HRBC membrane stabilization and albumin denaturation inhibition assay.

\section{HRBC membrane stabilization assay}

The inhibition of hypotonicity-induced HRBC membrane lysis, i.e., stabilization of HRBC membrane was taken as a measure of antiinflammatory activity. The percentage membrane stabilization and hemolysis for aqueous extracts and diclofenac sodium were done at $100,500,1000$, and $2000 \mu \mathrm{g} / \mathrm{ml}$. The aqueous extract of $P$. floridanus showed high percentage stabilization, i.e., $94.3 \pm 1.1$, and low percentage hemolysis, i.e., $7.6 \pm 1.5,9.66 \pm 1.5 \%$, while extracts prepared from Macrocybe sp. showed low percentage stabilization, i.e., $77.7 \pm 1.3$, and high percentage hemolysis, i.e., $36 \pm 1$. With the increasing concentration, the membrane hemolysis is decreased as shown in Table 5 while membrane stabilization/protection increases as shown in Table 6 . Diclofenac sodium was taken as standard showing excellent percentage stabilization, i.e., $96.28 \pm 0.8$ and lowest percentage hemolysis, i.e., $5 \pm 1$. Hence, anti-inflammatory activity of extracts was concentration dependent as shown in Table 5 and 6.

\section{Albumin denaturation inhibition assay}

Denaturation of proteins is well-documented cause of inflammation. The mechanism of the anti-inflammatory activity and the ability of extract protein denaturation were studied in the present investigation. All three aqueous extracts of mushrooms were effective in inhibiting heat-induced albumin denaturation. Maximum inhibition was observed from $P$. floridanus (86.5 \pm 0.7 ), followed by $P$. ostreatus (82.5 \pm 0.8 ), $T$.

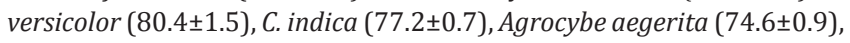
and Macrocybe sp. (73 \pm 0.7$)$ at concentration of $2000 \mu \mathrm{g} / \mathrm{ml}$. Diclofenac sodium, a standard anti-inflammation drug showed maximum inhibition $94.9 \pm 1.2$ for all isolates at concentration of $2000 \mu \mathrm{g} / \mathrm{ml}$ as shown in Table 7.

\section{DISCUSSION}

The antioxidant properties of fruits, vegetables, and mushrooms are due to the major contribution of polyphenols [25]. To study the importance of polyphenol compounds and their presence in the mushrooms, the estimation of these compounds in six isolates was done. The estimation of phenol was done by Folin-Ciocalteu's reagent by measuring the absorbance at $725 \mathrm{~nm}$. Estimation of flavonoids was done by ferric chloride method, and estimation of ascorbic acid was done by metaphosphoric method. Estimation of $\beta$ carotene and lycopene was done by Nagata and Yamashita [17].

Phenols are considered to be one of the major components of plants and mushrooms [26]. Due to the presence of hydroxyl group, these

Table 1: Bioactive compounds present in aqueous extract of isolates

\begin{tabular}{|c|c|c|c|c|c|}
\hline Mushrooms & Phenols (mg/g) & Flavonoid (mg/g) & $\beta$-carotene $(\mu \mathrm{g} / \mathrm{g})$ & Lycopene $(\mu \mathrm{g} / \mathrm{g})$ & Ascorbic acid (mg/g) \\
\hline Pleurotus ostreatus & $53.3 \pm 0.93^{b}$ & $13.02 \pm 0.12^{\mathrm{b}}$ & $8.384 \pm 0.42^{b}$ & $6.57 \pm 0.49^{b}$ & $12.01 \pm 0.89^{b}$ \\
\hline P. floridanus & $61.13 \pm 2.3^{\mathrm{a}}$ & $15.2 \pm 1.13^{\mathrm{a}}$ & $12.42 \pm 0.42^{\mathrm{a}}$ & $17.36 \pm 0.40^{\mathrm{a}}$ & $14.55 \pm 0.58^{\mathrm{a}}$ \\
\hline T. versicolor & $44.57 \pm 2.87^{c}$ & $11.44 \pm 0.12^{\mathrm{c}}$ & $7.17 \pm 1.17^{\mathrm{bc}}$ & $4.22 \pm 0.76^{\mathrm{cd}}$ & $8.68 \pm 0.59^{c}$ \\
\hline C. indica & $31.80 \pm 1.89^{d}$ & $7.98 \pm 0.17^{\mathrm{d}}$ & $5.62 \pm 0.43^{c}$ & $4.44 \pm 0.52^{\mathrm{c}}$ & $7.50 \pm 0.58^{c}$ \\
\hline A. aegerita & $25.89 \pm 1.42^{\mathrm{e}}$ & $7.37 \pm 0.11^{\text {de }}$ & $1.66 \pm 0.61^{d}$ & $3.03 \pm 0.31^{\text {de }}$ & $4.17 \pm 0.89^{d}$ \\
\hline Macrocybe sp. & $22.46 \pm 1.87^{e}$ & $6.24 \pm 0.11^{\mathrm{e}}$ & $0.979 \pm 0.42^{\mathrm{d}}$ & $1.75 \pm 0.51^{\mathrm{e}}$ & $2.77 \pm 0.03^{d}$ \\
\hline
\end{tabular}

A. aegerita: Agrocybe aegerita, C. indica: Calocybe indica, T. versicolor: Trametes versicolor, P. floridanus: Pleurotus floridanus, P. ostreatus: Pleurotus ostreatus.

$a, b, c, d, e$ : different letters means significant difference at $P<0.05$. Values are Mean $\pm S D(n=3)$ 
Table 2: Scavenging ability of aqueous extract from different isolates on 1, 1-diphenyl-2- picrylhydrazyl radicals

\begin{tabular}{|c|c|c|c|c|}
\hline \multirow[t]{2}{*}{ Isolates } & \multicolumn{4}{|c|}{$\begin{array}{l}\text { Concentration of extract used }(\mu \mathrm{g} / \mathrm{ml}) \\
\text { (Scavenging activity of free DPPH radicals) (\%) }\end{array}$} \\
\hline & 100 & 125 & 500 & 1000 \\
\hline P. ostreatus & $41.3 \pm 0.25^{c}$ & $46.9 \pm 0.2^{c}$ & $53.46 \pm 0.15^{c}$ & $62.33 \pm 0.15^{c}$ \\
\hline P. floridanus & $44.4 \pm 0.06^{\mathrm{b}}$ & $49.73 \pm 0.15^{\mathrm{b}}$ & $56.53 \pm 0.1^{\mathrm{b}}$ & $64.16 \pm 0.21^{\mathrm{b}}$ \\
\hline T. versicolor & $38.5 \pm 0.1^{\mathrm{d}}$ & $43.6 \pm 0.1^{\mathrm{d}}$ & $53.13 \pm 0.07^{\mathrm{d}}$ & $60.56 \pm 0.12^{\mathrm{d}}$ \\
\hline C. indica & $28.5 \pm 0.1^{\mathrm{e}}$ & $31.06 \pm 0.18^{\mathrm{e}}$ & $40.32 \pm 0.15^{\mathrm{e}}$ & $47.06 \pm 0.15^{\mathrm{e}}$ \\
\hline A. aegerita & $24.86 \pm 0.15^{\mathrm{f}}$ & $29.63 \pm 0.15^{\mathrm{f}}$ & $36.23 \pm 0.2^{\mathrm{f}}$ & $45.36 \pm 0.06^{\mathrm{f}}$ \\
\hline Macrocybe sp. & $21.06 \pm 0.2^{\mathrm{g}}$ & $27.43 \pm 0.15^{g}$ & $30.63 \pm 0.1^{g}$ & $38.76 \pm 0.15^{g}$ \\
\hline Ascorbic acid & $44.23 \pm 0.15^{\mathrm{a}}$ & $51.2 \pm 0.2^{\mathrm{a}}$ & $70.96 \pm 0.11^{\mathrm{a}}$ & $82.96 \pm 0.15^{\mathrm{a}}$ \\
\hline
\end{tabular}

Table 3: Scavenging ability of aqueous extract from different isolates on Nitric oxide free radicals

\begin{tabular}{lllll}
\hline Isolates & \multicolumn{4}{l}{$\begin{array}{l}\text { Concentration of extract used }(\boldsymbol{\mu g} / \mathbf{m l}) \\
\text { (Scavenging activity of } \mathbf{N O}_{2} \text { free radicals) }\end{array}$} \\
\cline { 2 - 5 } & $\mathbf{1 0 0}$ & $\mathbf{1 2 5}$ & $\mathbf{5 0 0}$ & $\mathbf{1 0 0 0}$ \\
\hline P. ostreatus & $27.13 \pm 0.06^{\mathrm{c}}$ & $37.4 \pm 0.57^{\mathrm{c}}$ & $47.37 \pm 0.06^{\mathrm{c}}$ & $60.76 \pm 0.57^{\mathrm{c}}$ \\
P. floridanus & $28.23 \pm 0.05^{\mathrm{b}}$ & $39.1 \pm 0.086^{\mathrm{b}}$ & $51.1 \pm 0.09^{\mathrm{b}}$ & $62.83 \pm 0.11^{\mathrm{b}}$ \\
T. versicolor & $24.7 \pm 0.12^{\mathrm{d}}$ & $33.5 \pm 0.11^{\mathrm{d}}$ & $42.96 \pm 0.12^{\mathrm{d}}$ & $56.37 \pm 0.06^{\mathrm{d}}$ \\
C. indica & $22 \pm 0.17^{\mathrm{e}}$ & $31.3 \pm 0.1^{\mathrm{e}}$ & $37.3 \pm 0.06^{\mathrm{e}}$ & $49.03 \pm 0.2^{\mathrm{e}}$ \\
A. aegerita & $20.06 \pm 0.2^{\mathrm{f}}$ & $23.6 \pm 0.6^{\mathrm{f}}$ & $30.46 \pm 0.5^{\mathrm{f}}$ & $36.1 \pm 0.17^{\mathrm{f}}$ \\
Macrocybe sp. & $18.42 \pm 0.04^{\mathrm{g}}$ & $22.01 \pm 0.15^{\mathrm{g}}$ & $28.5 \pm 0.17^{\mathrm{g}}$ & $33.63 \pm 0.05^{\mathrm{g}}$ \\
Ascorbic acid & $30.45 \pm 0.08^{\mathrm{a}}$ & $42.23 \pm 0.12^{\mathrm{a}}$ & $61.06 \pm 0.06^{\mathrm{a}}$ & $83 \pm 0.17^{\mathrm{a}}$
\end{tabular}

A. aegerita: Agrocybe aegerita, C. indica: Calocybe indica, T. versicolor: Trametes versicolor, P. floridanus: Pleurotus floridanus, P. ostreatus: Pleurotus ostreatus. $\mathrm{a}, \mathrm{b}, \mathrm{c}, \mathrm{d}, \mathrm{e}, \mathrm{f}, \mathrm{g}$ : different letters means significant difference at $\mathrm{P}<0.05$. Values are Mean \pm SD $(n=3)$

Table 4: Scavenging ability of aqueous extract from different isolates on hydrogen peroxide free radicals

\begin{tabular}{lllll}
\hline Isolates & \multicolumn{4}{l}{$\begin{array}{l}\text { Concentration of extract used }(\boldsymbol{\mu g} / \mathbf{m l}) \\
\text { (Scavenging activity of } \mathbf{H}_{\mathbf{2}} \mathbf{0}_{\mathbf{2}} \text { free radicals) } \mathbf{( \% )}\end{array}$} \\
\cline { 2 - 5 } & $\mathbf{1 0 0}$ & $\mathbf{1 2 5}$ & $\mathbf{5 0 0}$ & $\mathbf{1 0 0 0}$ \\
\hline P. ostreatus & $35.1 \pm 0.264^{\mathrm{c}}$ & $42.1 \pm 0.17^{\mathrm{c}}$ & $51.5 \pm 0.28^{\mathrm{c}}$ & $56.7 \pm 0.21^{\mathrm{c}}$ \\
P. floridanus & $39.46 \pm 0.15^{\mathrm{b}}$ & $46.06 \pm 0.15^{\mathrm{b}}$ & $54.3 \pm 0.31^{\mathrm{b}}$ & $62.21 \pm 0.16^{\mathrm{b}}$ \\
T. versicolor & $31.36 \pm 0.11^{\mathrm{d}}$ & $39.86 \pm 0.12^{\mathrm{d}}$ & $43.36 \pm 0.2^{\mathrm{d}}$ & $52.33 \pm 0.3^{\mathrm{d}}$ \\
C. indica & $28.6 \pm 0.2^{\mathrm{e}}$ & $34.03 \pm 0.25^{\mathrm{e}}$ & $42.3 \pm 0.2^{\mathrm{e}}$ & $49.4 \pm 0.3^{\mathrm{e}}$ \\
A. aegerita & $25.46 \pm 0.15^{\mathrm{f}}$ & $31.8 \pm 0.11^{\mathrm{f}}$ & $37.06 \pm 0.21^{\mathrm{f}}$ & $46.23 \pm 0.31^{\mathrm{f}}$ \\
Macrocybe sp. & $22.23 \pm 0.15^{\mathrm{g}}$ & $30.09 \pm 0.2^{\mathrm{g}}$ & $34.96 \pm 0.21^{\mathrm{g}}$ & $43.83 \pm 0.11^{\mathrm{g}}$ \\
Ascorbic acid & $46.69 \pm 0.2^{\mathrm{a}}$ & $51.53 \pm 0.15^{\mathrm{a}}$ & $60.5 \pm 0.2^{\mathrm{a}}$ & $75 \pm 0.17^{\mathrm{a}}$
\end{tabular}

$\begin{array}{llll}\text { Ascorbic acid } \quad 46.69 \pm 0.2^{\mathrm{a}} \quad 51.53 \pm 0.15^{\mathrm{a}} & 60.5 \pm 0.2^{\mathrm{a}} \quad 75 \pm 0.17^{\mathrm{a}}\end{array}$

A. aegerita: Agrocybe aegerita, C. indica: Calocybe indica, T. versicolor: Trametes versicolor, P. floridanus: Pleurotus floridanus, P. ostreatus: Pleurotus ostreatus. $a, b, c, d, e, f, g$ : Different letters means significant difference at $P<0.05$. Values are Mean $\pm \operatorname{SD}(n=3)$

are known to eliminate free radicals and also associated with the antioxidant effect of whole system [27]. In the earlier studies, it was observed that higher content of phenols due to their redox properties accounts for better free radical scavenging effects and can play an important role in absorbing in neutralizing quenching of free radicals singlet and triplet oxygen or decomposing peroxides [28]. Ascorbic acid is a compound that occurs naturally having antioxidant properties that are necessary for wound healing and strengthening of blood vessels. Flavonoids, on the other hand, are known to be most promising polyphenolic compound having a broad spectrum of chemical and biological activities that includes radical scavenging activity, antiviral, anti-allergic, anti-inflammatory, and vasodilating action. It has been also found in various studies that out of many pharmacological effects of phenol and flavonoids are linked together and act as free radical scavengers and strong antioxidants. Carotenoids including $\beta$ carotene and lycopene exert an antioxidant function that includes quenching of singlet oxygen and other electronically excited molecules and progression of degenerative diseases [29].

In the present study, it was revealed that the aqueous extract taken for quantitative analysis constitutes phenolic compounds in good amount. These compounds possess antioxidant functions; hence, the studied mushrooms can be harnessed in the management of oxidative stress induced disease.

In a wide variety of pathological manifestation free radicals are known to play a definite role, therefore, search of natural scavenger of reactive oxygen and nitrogen species seems to be highly desirable to protect against oxidative stress responsible for causing numerous diseases.

Being free radical DPPH has the advantage of being unaffected by certain side reaction that includes metal ion chelation and enzyme inhibition [23]. DPPH exhibit deep purple when prepared freshly with maximum absorption at $517 \mathrm{~nm}$, due to quenching of its free radicals by antioxidants present in the medium the deep purple colour disappears, i.e., by electron donation or by providing hydrogen atom via free radical attack on DPPH molecule and convert them to colourless bleached product known as 2,2 diphenyl-1 hydrazine. This results in decrease in the absorption at $517 \mathrm{~nm}$, hence, more rapidly the decrease in absorbance more potent the antioxidant activity of the extract [30]. The results of the present investigation suggest that the mycelial cultures of mushrooms contain phytochemicals constituents that are capable of donating hydrogen to a free radical to scavenge the potential damage.

Nitric oxide is a free radical present in mammalian cells responsible for the regulation of physiological processes. Excess production of NO is associated with several diseases [31]. Under aerobic conditions, it reacts with oxygen to produce stable products known as nitrate and nitrite. Nitric oxide can be toxic if present in higher concentration, therefore, its inhibition is an important goal.

Hydrogen peroxide occurs naturally at lower concentration levels in air, water plants, microorganisms, food, and human body [32]. It has strong oxidizing properties and can be formed in vivo by oxidizing enzymes such as superoxide dismutase. It can slowly oxidize a number of compounds by crossing the membrane. Hydrogen peroxide is rapidly composed into oxygen and water which results in the production of $(-\mathrm{OH})$ that initiate lipid per-oxidation which leads to DNA damage [33]. Aqueous extract of mushroom's mycelial cultures effectively scavenged hydrogen peroxide and may attribute to the presence of phenolic groups that can donate electrons to hydrogen peroxide, thereby neutralizing it into water.

In the present study, free radical scavenging assay of aqueous extract of six mushrooms mycelial cultures was tested, and it was revealed that $P$. floridanus have great potential of antioxidant activity while Macrocybe sp. have least one.

For in vitro assessment of anti-inflammatory properties of extracts of all mushrooms isolates. Hypotonicity-induced HRBC membrane stabilization and albumin denaturation bioassay were selected. By inhibiting hypotonicity-induced lysis of erythrocyte membrane, the extract exhibits membrane stabilization effect. The erythrocytes stabilization implies that the extract may stabilize the lysosomal membrane because it is analogous to lysosomal membrane [34]. In limiting, the inflammatory response by preventing the release of lysosomal constituents of activated neutrophil such as bactericidal enzymes and proteases, which cause further tissue inflammation and damage on extracellular release lysosomal membrane stabilization is important [35]. It is believed that some of the NSAIDs are known to possess membrane stabilization properties which may contribute to the potency of their anti-inflammatory effect. The exact mechanism of the membrane stabilization by the extract is not known 
Table 5: Effect of aqueous extract and standard on HRBC membrane hemolysis

\begin{tabular}{llllllll}
\hline Concentration $(\boldsymbol{\mu g} / \mathbf{m l})$ & \multicolumn{2}{l}{$\%$} \\
& \% hemolysis of isolates & & & \\
& Diclofenac sodium & P. ostreatus & P. floridanus & T. versicolor & C. indica & A. aegerita & Macrocybe sp. \\
\hline 100 & $56 \pm 2^{\mathrm{e}}$ & $68.3 \pm 1.5^{\mathrm{c}}$ & $63 \pm 1^{\mathrm{d}}$ & $78.6 \pm 1.5^{\mathrm{b}}$ & $82.3 \pm 1.5^{\mathrm{b}}$ & $87.6 \pm 1.5^{\mathrm{a}}$ & $91.6 \pm 1.5^{\mathrm{a}}$ \\
500 & $39 \pm 1^{\mathrm{f}}$ & $51 \pm 1^{\mathrm{e}}$ & $39.3 \pm 1.5^{\mathrm{f}}$ & $56.3 \pm 1.5^{\mathrm{d}}$ & $60 \pm 1^{\mathrm{c}}$ & $63.6 \pm 1.5^{\mathrm{b}}$ & $75 \pm 1^{\mathrm{a}}$ \\
1000 & $11.6^{\mathrm{a}} \pm 1.5^{\mathrm{e}}$ & $18.6 \pm 1.5^{\mathrm{cd}}$ & $14.6 \pm 1.5^{\mathrm{de}}$ & $20.3 \pm 2.1^{\mathrm{c}}$ & $23 \pm 2^{\mathrm{c}}$ & $28.3 \pm 1.5^{\mathrm{b}}$ & $36 \pm 1^{\mathrm{a}}$ \\
2000 & $5 \pm 1^{\mathrm{d}}$ & $14.3 \pm 1.5^{\mathrm{c}}$ & $7.6 \pm 1.5^{\mathrm{d}}$ & $16 \pm 1^{\mathrm{c}}$ & $20.6 \pm 1.5^{\mathrm{b}}$ & $24 \pm 1^{\mathrm{b}}$ & $30 \pm 2^{\mathrm{a}}$ \\
\hline
\end{tabular}

A. aegerita: Agrocybe aegerita, C. indica: Calocybe indica, T. versicolor: Trametes versicolor, P. floridanus: Pleurotus floridanus, P. ostreatus: Pleurotus ostreatus.

$a, b, c, d, e$ : Different letters means significant difference at $\mathrm{P}<0.05$. Values are Mean \pm SD $(n=3)$

Table 6: Effect of aqueous extract and standard on HRBC membrane stabilization

\begin{tabular}{|c|c|c|c|c|c|c|c|}
\hline \multirow[t]{2}{*}{ Concentration $(\mu \mathrm{g} / \mathrm{ml})$} & \multicolumn{7}{|c|}{$\%$ stabilization of isolates } \\
\hline & Diclofenac sodium & P. ostreatus & P. floridanus & T. versicolor & C. indica & A. aegerita & Macrocybe sp. \\
\hline 100 & $58.5 \pm 1.8^{\mathrm{a}}$ & $49.1 \pm 0.5^{c}$ & $53.3 \pm 0.6^{\mathrm{b}}$ & $41.6 \pm 1.4^{\mathrm{d}}$ & $38.8 \pm 1.2^{\mathrm{d}}$ & $35.05 \pm 1^{\mathrm{e}}$ & $32.1 \pm 1.5^{\mathrm{e}}$ \\
\hline 500 & $76.3 \pm 1.3^{\mathrm{a}}$ & $62.2 \pm 0.4^{c}$ & $70.8 \pm 1.2^{\mathrm{b}}$ & $58.2 \pm 0.83^{\mathrm{d}}$ & $55.5 \pm 0.9^{\mathrm{de}}$ & $52.7 \pm 1.4^{\mathrm{e}}$ & $44.4 \pm 0.3^{\mathrm{f}}$ \\
\hline 1000 & $91.4 \pm 1.1^{\mathrm{a}}$ & $86.2 \pm 1.2^{\mathrm{bc}}$ & $89.1 \pm 1.1^{\mathrm{ab}}$ & $84.7 \pm 1.6^{c}$ & $82.9 \pm 1.4^{c}$ & $78.9 \pm 1.3^{\mathrm{d}}$ & $73.3 \pm 0.9^{\mathrm{e}}$ \\
\hline 2000 & $96.3 \pm 0.7^{\mathrm{a}}$ & $89.4 \pm 1.2^{\mathrm{b}}$ & $94.3 \pm 1.1^{\mathrm{a}}$ & $88.14 \pm 0.7^{b}$ & $84.6 \pm 1.2^{\mathrm{c}}$ & $82.2 \pm 0.7^{c}$ & $77.7 \pm 1.3^{\mathrm{d}}$ \\
\hline
\end{tabular}

A. aegerita: Agrocybe aegerita, C. indica: Calocybe indica, T. versicolor: Trametes versicolor, P. floridanus: Pleurotus floridanus, P. ostreatus: Pleurotus ostreatus.

$\mathrm{a}, \mathrm{b}, \mathrm{c}, \mathrm{d}, \mathrm{e}$ : Different letters means significant difference at $\mathrm{P}<0.05$. Values are Mean $\pm \mathrm{SD}(n=3)$

Table 7: Effect of aqueous extract of mushrooms on albumin denaturation

\begin{tabular}{|c|c|c|c|c|c|c|c|}
\hline \multirow[t]{2}{*}{ Concentration $(\mu \mathrm{g} / \mathrm{ml})$} & \multicolumn{7}{|l|}{$\%$ inhibition } \\
\hline & Diclofenac sodium & P. ostreatus & P. floridanus & T. versicolor & C. indica & A. aegerita & Macrocybe sp. \\
\hline 100 & $43.1 \pm 1.3^{\mathrm{a}}$ & $31.54 \pm 2.3^{b}$ & $35.2 \pm 1.6^{\mathrm{b}}$ & $26.2 \pm 1.4^{c}$ & $24.6 \pm 0.2^{\text {cd }}$ & $23 \pm 1.2^{\text {cd }}$ & $21.9 \pm 1.2^{\mathrm{d}}$ \\
\hline 500 & $60.04 \pm 1.3^{\mathrm{a}}$ & $44.4 \pm 0.66^{\mathrm{bc}}$ & $47.1 \pm 1.4^{\mathrm{b}}$ & $42.3 \pm 1.5^{\mathrm{cd}}$ & $41.3 \pm 1.1^{\mathrm{de}}$ & $38.9 \pm 0.3^{\mathrm{e}}$ & $34.9 \pm 0.3^{\mathrm{f}}$ \\
\hline 1000 & $88.6 \pm 1.2^{\mathrm{a}}$ & $72.2 \pm 0.6^{c}$ & $80.15 \pm 0.7^{b}$ & $70.6 \pm 0.9^{c d}$ & $69.1 \pm 0.7^{\mathrm{d}}$ & $64.3 \pm 0.9^{\mathrm{e}}$ & $57.1 \pm 0.7^{\mathrm{f}}$ \\
\hline 2000 & $94.9 \pm 1.2^{\mathrm{a}}$ & $82.5 \pm 0.8^{c}$ & $86.5 \pm 0.7^{b}$ & $80.4 \pm 1.5^{c}$ & $77.2 \pm 0.7^{\mathrm{d}}$ & $74.6 \pm 0.9^{\mathrm{de}}$ & $73 \pm 0.7^{\mathrm{e}}$ \\
\hline
\end{tabular}

A. aegerita: Agrocybe aegerita, C. indica: Calocybe indica, T. versicolor: Trametes versicolor, P. floridanus: Pleurotus floridanus, P. ostreatus: Pleurotus ostreatus.

$a, b, c, d, e$ : Different letters means significant difference at $\mathrm{P}<0.05$. Values are Mean $\pm \operatorname{SD}(n=3)$

yet, and it is believed that hypotonicity-induced hemolysis may arise from shrinkage of the cells due to osmotic loss of intracellular electrolyte and fluid components.

Denaturation of tissue proteins was another cause of inflammatory disease [36]. For the anti-inflammatory drug development of agents that can prevent protein denaturation would be worthwhile. The stabilization of protein is indicated by the increments in absorbance of test samples with respect to control, i.e., inhibition of heat-induced protein (albumin) denaturation by extracts and reference drug diclofenac sodium [37].

The anti-denaturation effect was further supported by the change in viscosities. The viscosities of protein solutions increase on denaturation [38]. The relatively high viscosity of control dispersion substantiated this fact in the present study. The presence of all mushroom extracts taken in the study prevented this, implying inhibition of protein denaturation. The viscosities decreased when compared with control where no test extract/drug was added. However, the viscosities were found to decrease with concomitant decrease in concentration of test extract and reference drug as well. Although the viscosities of the test samples (extract/drug) of all concentrations were always less than that of control. This decrease in viscosities may be due to decrease in concentration of test extract/drug in reaction mixture, which resulted in decreased viscosity; and/or other uncertain physicochemical factors. Nevertheless, the viscosity data indicated inhibition of protein (albumin) denaturation. Further studies are required to study the effect of concentration of test agent on viscosity behavior of denatured protein dispersion.

\section{CONCLUSION}

The present study has been focused on antioxidant and antiinflammatory potential of six mushrooms and determination of their chemical composition in terms of phenolic compounds. Mushrooms consist of biologically active substances that act as remarkable products and can diversify everyday human diet as well as utilize for their medicinal properties. Hence, there is a great need of exploiting these mushrooms to new drug discovery.

\section{ACKNOWLEDGMENTS}

The authors are grateful to the Department of Biotechnology, Shoolini University of Biotechnology and Management Sciences, Solan, India, for support and institutional facilities.

\section{REFERENCES}

1. Heleno SA, Barros L, Sousa MJ, Martins A, Ferreira IC. Study and characterization of selected nutrients in wild mushrooms from Portugal by gas chromatography and high performance liquid chromatography. Microchem J 2009;93(2):195-99.

2. Kalac P. Chinese composition and nutritional value of European species of wild growing mushrooms a review. Food Chem 2009;113:9-16.

3. Kalac P. Chemical composition and nutritional value of European species of wild growing mushrooms. In: Andres S, Baumann N, editors. Mushrooms: Types Properties and Nutrition. New York: Nova Science Publishers; 2012. p. 130-51.

4. Bains A, Tripathi A. Antioxidant and anti-inflammatory properties of wild mushrooms collected from Himachal Pradesh. World J Pharm Res 2015;4(8):1507-20.

5. Wang Y. IR. Hall. Edible ectomycorrhizal mushrooms: Challenges and achievements. Can J Bot 2004;82(8):1063-73.

6. Alves MJ, Ferreira IC, Martins A, Pintado M. Antimicrobial activity of wild mushroom extracts against clinical isolates resistant to different antibiotics. J Appl Microbiol 2012;113(2):466-75.

7. Ferreira IC, Barros L, Abreu RM. Antioxidants in wild mushrooms. Curr Med Chem 2009;16(12):1543-60.

8. Klein E, Smith DL. Laxminarayan R. Hospitalizations and deaths caused by methicillin-resistant Staphylococcus aureus, United States, 
1999-2005. Emerg Infect Dis 2007;13(12):1840-6.

9. Circu ML, Aw TY. Reactive oxygen species, cellular redox systems, and apoptosis. Free Radic Biol Med 2010;48(6):749-62.

10. Jeong EM, Liu M, Sturdy M, Gao G, Varghese ST, Sovari AA, Dudley SC Jr. Metabolic stress, reactive oxygen species, and arrhythmia. J Mol Cell Cardiol 2012;52(2):454-63.

11. Closa D, Folch-Puy E. Oxygen free radicals and the systemic inflammatory response. IUBMB Life 2004;56(4):185-91.

12. Grice HC. Safety evaluation of butylated hydroxyanisole from the perspective of effects on forestomach and oesophageal squamous epithelium. Food Chem Toxicol 1988;26(8):717-23.

13. Mackerras D. Antioxidant and health. Fruits and vegetables or supplements. Food Aust 1995;47:3-23.

14. Singleton VL, Orthofer R, Lamuela-Raventos RM. Analysis of total phenols ad other oxidation substrates and antioxidants by means of Folin-Ciocalteau's reagent. Methods Enzymol 1999;299:1520-78.

15. Jia ZS, Tang MC, Wu JM. The determination of flavonoid contents in mulberry and their scavenging effects on superoxide radicals. Food Chem 1999;64(4):555-99.

16. Klein BP, Perry AK. Ascorbic acid and Vitamin A activity in selected vegetables from different geographical areas of United States. J Food Sci 1982;47(3):941-5.

17. Nagata M, Yamashita I. Simple method for stimultaneous determination of chlorophyll and carotenoids in tomato fruits. Nippon Shokuhin Kogyo Gakkaish 1992;39(10):925-8.

18. Prasanth NV, Dilip C, Sanal Dev KT, Augustine L, Sarswathi R. Evaluation of in vitro cytotoxic and antioxidant activities of Ipomoea batatas. Int J Pharm Pharm Sci 2010;2(3):91-2.

19. Sachin SS, Archana R, Juvekar, Manoj N, Gambhire. In vitro anti oxidant and anti-inflammatory activity of methanol extract of Oxalis corinculata linn. Int J Pharm Pharm Sci 2010;2(1):146-55.

20. Khaled-Khodjaa N, Boulekbache-Makhloufb L, Madani K. Phytochemical screening of antioxidant and antibacterial activities of some Laminaceae. Industrial crops and products 2014;61:41-8.

21. Chippada SC, Volluri SS, Bammidi SR, Vanglapati M. In vitro antiinflammatory activity of methanolic extract of Centella asiatica by HRBC membrane stabilisation. Rasayan J Chem 2011;4(2):457-60.

22. Chandra S, Chatterjee P, Dey P, Bhattacharya S. Evaluation of in vitro anti-inflammatory activity of coffee against the denaturation of protein. Asian Pac J Trop Biomed 2012;2(1):S178-80

23. Amarowiez R, Pegg RB, Moghddam PR, Barl B, Weil JA. Free radical scavenging capacity and antioxidant activity of selected plant species from the Canadian prairies. Food Chem 2004;84(4):551-62.

24. Wagay JA, Vyas D. Phenolic quantification and antioxidant activity of
Morchella esculenta. Int J Pharm Biosci 2011;2(1):188-97.

25. Ferreira IC, Baptista P. Vilas-Boas M, Barros L. Free radical scavenging capacity and reducing power of wild edible mushrooms from northeast Portugal: Individual cap and stipe activity. Food Chem 2007;100(4):1511-6

26. Barros LM, Ferreira B, Queiros IC, Ferreira FR, Baptista P. Total phenols, ascorbic acid, b-carotene and lycopene in Portuguesewild edible mushrooms and their antioxidant activities. Food Chem 2007;103(3):413-9

27. Duh PD, Tu YY, Yen GC. Antioxidant activity of water extract of harnjyur Chyrsanthemumm orifolium (Ramat). Lebensmittel Wissenschaft Technol 1999;32(5):269-77.

28. Mishra T, Das AP, Sen A. Phytochemical screening and in vitro antioxidant profiling of solvent fraction of Canna edulis KerGawler. Free Rad Antiox 2012;2(1):13-20.

29. Parajuli S, Pun NT, Parajuli S, Jamakattel-Pandit N. Antioxidant activity, total phenol and flavonoid contents in some selected medicinal plants of Nepal. JHAS 2012;2(1):27-31.

30. Bains A, Sharma A, Tripathi A. Antibacterial and antioxidant properties of wild mushrooms collected from Himachal Pradesh. Int J Biol Pharm Allied Sci 2015;4(10):6161-70.

31. Sindhu ER, Preethi KC, Kuttan R. Antioxidant activity of carotenoid lutein in-vitro and in-vivo. Indian J Exp Biol 2010;48(8):843-8.

32. Ray G, Hussain SA. Oxidants and antioxidants and carcinogenesis. Indian J Exp Biol 2002;40(11):1214.

33. Wang BS, Chen JH, Leang YC, Duh PD. Effect of welsh onion on oxidation of low density lipoprotein and nitric oxide production in macrophage cell line RAW 264.7. Food Chem 2005;91(1):47.

34. Gulcin I. The antioxidant and radical scavenging avtivity of black pepper (Piper nigrum) seeds. Int J Food Sci Nutr 2005;56:491-9.

35. Sahreen S, Khan MR, Khan RA. Estimation of flavonoids and evaluation of protective effect of Carissa opaca Stapf ex Haines fruit against CC14 induced nephrotoxicity in rat. Food Chem Toxicol 2011;10:54.

36. Mounnissamy VM, Kavimani S, Balu V, Drlin QS. Evaluation of anti- inflammatory and membrane stabilizing properties of ethanol extract of Canjerarehedi. Iran J Pharmacol Ther 2008;6:235-7.

37. Chaitanya R, Sandhya S, David B, Vinod KR, Murali S. HRBC membrane stabilizing property of roor, stem and leaf of Glochidion velutinum. Int J Res Pharmaceut Biomed Sci 2011;2(1):256-9.

38. Umapathy E, Ndebia EJ, Meeme A, Adam B, Menziwa P, Nkeh-Chungag BN, et al. An experimental evaluation of Albucasetosa aqueous extract on membrane stabilization, protein denaturation and white blood cell migration during acute inflammation. J Med Plants Res 2010;4(9):789-95. 